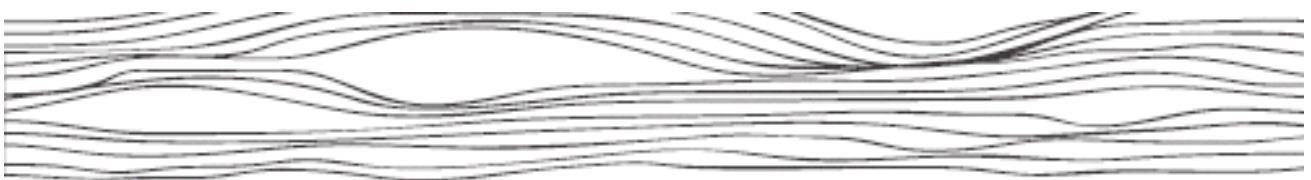

Public Space: The Journal of Law and Social Justice

\title{
DELIVERY OF ADVICE TO MARGINALISED AND VULNERABLE GROUPS: THE NEED FOR INNOVATIVE APPROACHES ${ }^{1}$
}

\author{
Alexy Buck ${ }^{2}$ and Liz Curran ${ }^{3}$
}

\begin{abstract}
Knowledge, capacity, capability and understanding are the key pre-requisites to access to justice. ${ }^{4}$ If legal aid services are to be effective in reaching people who are disadvantaged, disempowered or marginalised, then integrated, connected service delivery, outreach and relationship building, community development and education play a vital role. This article presents selected research findings from England and Wales, and Australia, illustrating the advice needs of disadvantaged groups. It further presents four delivery models from around the world, which all aim for innovation and flexibility. The article concludes with a number of key issues to consider when delivering advice to marginalised and vulnerable groups.
\end{abstract}

\section{Introduction}

In order for policy makers and practitioners to tailor advice to vulnerable, disempowered and/or marginalized groups, an understanding of how these groups

\footnotetext{
${ }^{1}$ The authors would like to thank Zofia Bajorek and Catrina Denvir for valuable help in finalising this article.

${ }^{2}$ Head, Legal Services Research Centre, Legal Services Commission, London, United Kingdom. This article reflects the views of the authors, and not necessarily those of the Legal Services Commission of England and Wales.

${ }^{3}$ Director, West Heidelberg Community Legal Service (formerly La Trobe University, School of Law), Victoria, Australia. Research undertaken by her for this article was partly supported with funding from the Victorian Law Foundation in 2007.

${ }^{4}$ L Curran and M Noone, 'The Challenge of Defining Unmet Legal Need' (2007) 63 Journal of Law and Social Policy, 63-64.
}

Public Space: The Journal of Law and Social Justice (2009) Vol 3, Art 7, pp 1-29. 


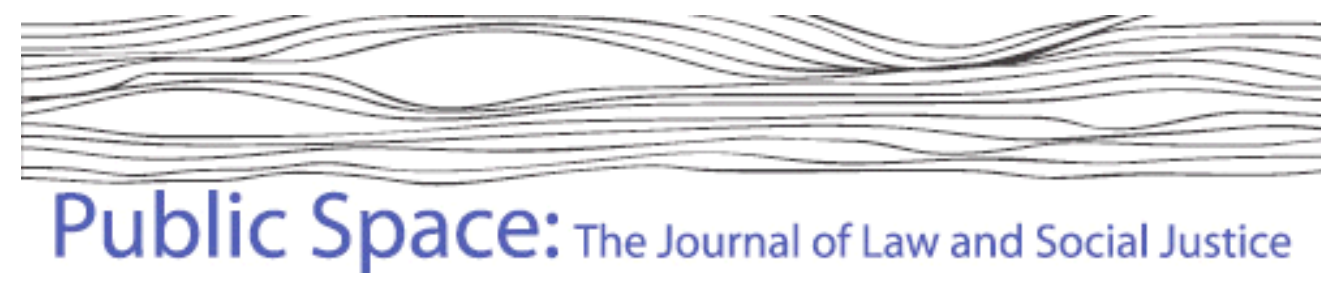

experience legal problems, and how they access legal aid services is necessary ${ }^{5}$, as is an understanding of the broader context in which the individual experiences a problem. People may be marginalized by virtue of their social exclusion, disempowered as a result of a lack of resources, and/or vulnerable on account of mental health or other issues. Legal advice services which fail to address the delivery requirements of vulnerable groups are likely to be ineffective in assisting these groups.

Much research over the last decade has sought to understand legal problems within a broader construct of social disadvantage and vulnerability. Legal issues rarely occur in a vacuum and are often triggered by underlying problems; or lead to further problems. Providing services which assist vulnerable groups, requires an appreciation of both the type of services that should be delivered, as well as the method in which they should be delivered.

This article highlights selected research on the needs of vulnerable, disadvantaged and 'hard to reach' groups, and the scope of and interconnectivity between legal and social problems. Some policy responses to these research findings are detailed. The article then provides brief overviews of four advice models from around the world. Whilst it is outside the remit of this article to evaluate these models, they nevertheless provide examples of approaches which seek innovation and flexibility. The article concludes with a number of key issues to consider when delivering advice to marginalized and vulnerable groups. These include the co-ordination and integration

\footnotetext{
${ }^{5}$ In this article, the term 'legal aid services' includes legal aid services provided by the private legal profession and by not-for-profit organisations, salaried legal aid lawyers within legal aid commissions, community legal centres (including neighbourhood law centres and law centres in general) and other publicly funded services which provide legal information, advice and representation to people. Vulnerable, disempowered and marginalized groups are defined as: people with limited income, employment opportunities and education, minimal power, living in poverty or communities that are deprived, under-resourced, and/or lack sufficient infrastructure. It also includes persons who suffer some form of disadvantage due to their state of mental health, disability, racial or cultural background, age, or a combination of all these.
}

Public Space: The Journal of Law and Social Justice (2009) Vol 3, Art 7, pp 1-29. 


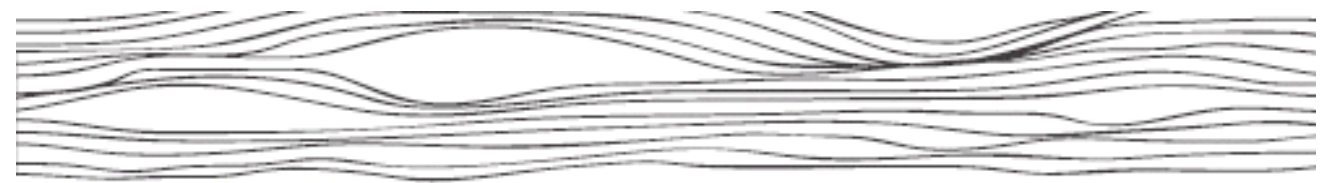

Public Space: The Journal of Law and Social Justice

of legal and other advice services, alternative methods of delivery such as outreach, and community legal education.

\section{The legal advice needs of vulnerable and marginalized groups - what does research indicate?}

\section{Selected Evidence from England and Wales: the English and Welsh Civil and Social Justice Survey}

The Legal Services Research Centre (LSRC), the independent research division of the Legal Services Commission (LSC) of England and Wales, is responsible for the English and Welsh Civil and Social Justice Survey (CSJS). The survey exemplifies the importance attached to research in civil justice policy-making in England and Wales. The LSRC receives government funding to conduct this large-scale representative household survey on the nature, patterns and impact of people's experience of civil justice problems, and the use and success of problem resolution strategies. $^{7}$ The survey is a development upon the earlier groundbreaking work of Genn, and Genn and Paterson. ${ }^{8}$ Similar surveys have now also been undertaken in other jurisdictions, for example in the Netherlands ${ }^{9}$, Canada $^{10}$ and New Zealand. ${ }^{11}$

Drawing on Genn's work, civil justice problems, or 'justiciable' problems, are defined as problems which raise civil legal issues, whether or not recognised by a survey respondent as being legal, and whether or not any action taken by the respondent to

\footnotetext{
${ }^{6}$ See www.lsrc.org.uk.

${ }^{7}$ P Pleasence Causes of Action: Civil Law and Social Justice, $2^{\text {nd }}$ ed (2006).

${ }^{8}$ H Genn, Paths to Justice (1999); H.Genn and A Paterson, Paths to Justice Scotland (2001).

${ }^{9}$ BCJ van Velthoven, and MJ ter Voert, Paths to Justice in the Netherlands (2005), paper presented at the International Legal Aid Group (ILAG) Conference, Killarney, Ireland, June 2005.

${ }^{10}$ A Currie, 'A National Survey of the Civil Justice Problems of Low and Moderate Income Canadians: Incidence and Patterns' (2006) 13 International Journal of the Legal Profession 217-242.

${ }^{11}$ Ignite Research, Report on the 2006 National Survey of Unmet Legal Needs and Access to Services (2006).
}

Public Space: The Journal of Law and Social Justice (2009) Vol 3, Art 7, pp 1-29. 


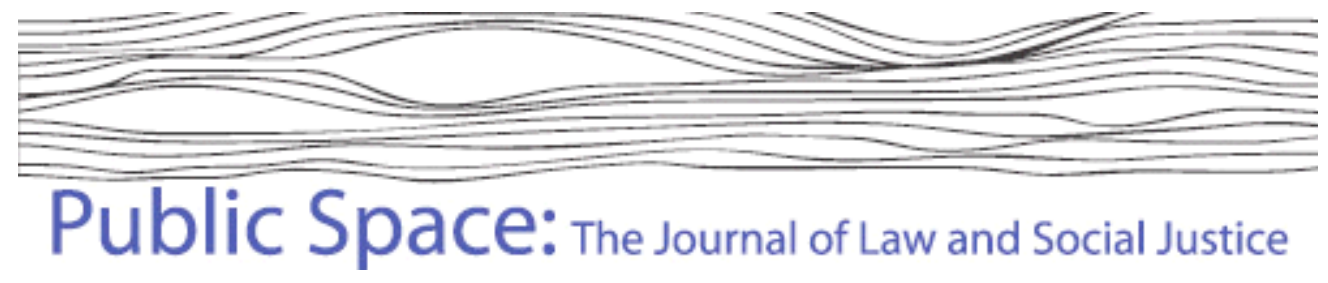

deal with the event involved the use of any part of the civil justice system. The fieldwork for the first LSRC national survey was conducted in 2001, with the second survey taking place in 2004. Reflecting the impact the survey has had on policy and research, it became a continuous survey in January 2006, meaning fieldwork was conducted monthly. The survey is now being developed even further, turning into a longitudinal panel survey from 2010 onwards.

To exemplify the scope and structure of the CSJS, an overview of the 2004 survey follows. Interviews were arranged and conducted by BMRB Social Research between July and December 2004. ${ }^{12}$ The interviews were face-to-face and took place in the respondents' homes. Respondents completed a screening interview, where they were asked if they had experienced a problem since January 2001 that had been difficult to solve, in each of eighteen distinct problem types: consumer, neighbours, money/debt, employment, negligent accidents, housing (renting), housing (owning), discrimination, divorce, welfare benefits, relationship breakdown, clinical negligence, children, housing (homelessness), domestic violence, unfair police treatment, immigration, and mental health.

The screen interview was carefully constructed to limit (as far as possible) the circumstances reported to those to which legal principles can be applied. For the two most recent problems identified in each category, respondents were asked about their nature, action taken to resolve them, manners of conclusion, and impact on their lives. As part of this, they were asked whether, as a result of any given problem, they had experienced physical ill-health, stress related illnesses, relationship breakdown, personal violence, property damage, loss of a home, loss of employment, loss of

\footnotetext{
${ }^{12}$ Residential addresses were randomly selected from 250 postcode sectors, spread throughout England and Wales, using the small user Postcode address file. Adults over 18 years of age within each of 3,832 households were interviewed, yielding 5,015 respondents. Seventy-two per cent of adult household members (over 18 years of age) were interviewed. The household response rate was 79 per cent ( 89 per cent where successful contact was made with an adult occupant), and the cumulative eligible adult response rate was 57 per cent.
}

Public Space: The Journal of Law and Social Justice (2009) Vol 3, Art 7, pp 1-29. 


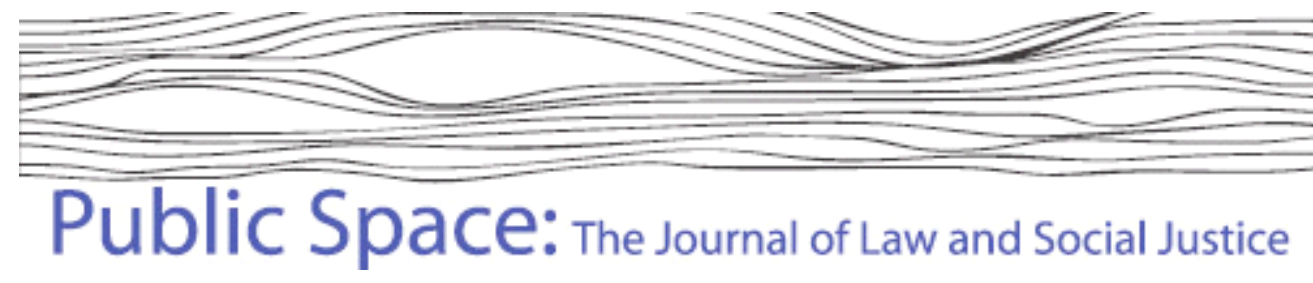

income or loss of confidence. All respondents were asked for a range of demographic details about themselves and the household in which they resided.

If a respondent had experienced at least one problem, they progressed to a short follow-up interview, addressing further aspects of a single problem drawn from those identified through the screening interview (including advice, objectives, costs and outcomes). Twenty-two per cent of respondents completed both a screen and a follow-up interview. The mean total interview duration was half an hour. A full technical report of the survey has been published elsewhere. ${ }^{13}$

In total, 5,015 respondents were interviewed, with 33 per cent of respondents reporting having experienced one or more civil justice problems in the three-and-ahalf year survey reference period.

Data produced by the 2001, 2004, and continuous CSJS have allowed for a wide variety of research opportunities. Findings include those on multiple problems and problem clusters ${ }^{14}$ and detailed analysis of the experiences of vulnerable groups including; young people, ${ }^{15}$ the homeless, and lone parents. ${ }^{16}$ Regarding these and other vulnerable groups, the LSRC has stated that:

not doing anything about the problem points to the lack of knowledge about the seriousness of the problem and what action to take, and being able to

${ }^{13}$ A Phelps, B Hayward and T Hanson, 2004 English and Welsh Civil and Social Justice Survey: Technical Report (2005).

${ }^{14}$ See for example P Pleasence, NJ Balmer, A Buck, A O'Grady and H Genn, 'Multiple Justiciable Problems: Common Clusters, Problem Order and Social and Demographic Indicators' (2004) 1 Journal of Empirical Legal Studies 301-29.

15 NJ Balmer, T Tam, and P Pleasence, Young People and Civil Justice: Findings from the 2004 English and Welsh Civil and Social Justice Survey (2007); LSRC Young People, Advice and Mental Health: A Data Digest (2009), both available at www.lsrc.org.uk

${ }^{16}$ A Buck, P Pleasence, NJ Balmer, A O'Grady and H Genn, 'Lone Parents and Civil Law: Their Experience of Problems and Their Advice Seeking Behaviour' (2004) 38 Social Policy and Administration.

Public Space: The Journal of Law and Social Justice (2009) Vol 3, Art 7, pp 1-29. 


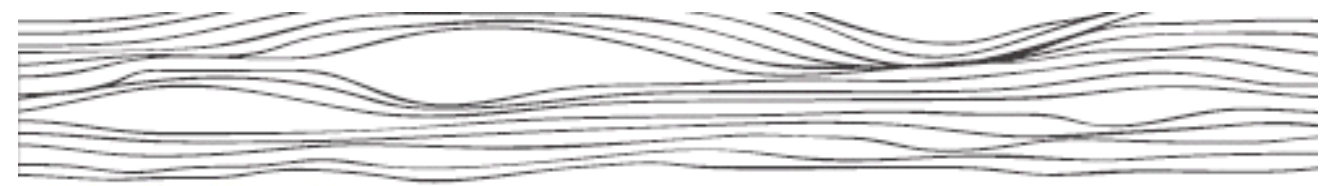

Public Space: The Journal of Law and Social Justice

handle a problem alone requires expertise, confidence and also monetary resources. It is certainly the case that sometimes people are more than able to deal with problems alone, and sometimes it might be reasonable to make no attempt to resolve the problem. No one strategy to deal with problems can be universally prescribed. However, particularly for those people who face problems of social exclusion, and may be the least able to solve problems themselves, clear information and assistance may be vital to enable them to escape from civil justice problems that might well act to entrench or even worsen their predicament. ${ }^{17}$

Importantly, further results from the CSJS, ${ }^{18}$ along with research of Moorhead and others, ${ }^{19}$ have highlighted that civil justice problems can impact upon people's health and well-being, potentially increasing anxiety and stress. ${ }^{20}$

${ }^{17}$ A Buck, NJ Balmer and P Pleasence, 'Social Exclusion and Civil Law: Experience of Civil Justice problems among Vulnerable Groups' (2005) 39 Journal of Social Policy and Administration, 302320.

${ }_{18}$ P Pleasence, NJ Balmer, T Tam, A Buck, M Smith and A Patel, Civil Justice in England and Wales: Report of the 2007 English and Welsh Civil and Social Justice Survey (2008), available at www.lsrc.org.uk; P Pleasence, NJ Balmer and A Buck, 'Health Professionals as Rights Advisers: Rights Advice and Primary Healthcare Services' (2007); P Pleasence, NJ Balmer, A Buck, A O'Grady and H Genn, 'Civil Law Problems and Morbidity' (2004) 58 Journal of Epidemiology and Community Health.

${ }^{19}$ L Sherr, A Sherr, R Harding, R Moorhead and S Singh, Reducing Poverty: Welfare Rights and Health Inequalities (2002); R Moorhead, M Robinson, and Matrix Research and Consultancy, A Trouble Shared-Legal Problems Clusters in Solicitors and Advice Agencies (2006).

${ }^{20}$ See also GR Kitson and LA Morgan, 'The multiple consequences of divorce: a decade review' (1990) 52 Journal Marriage and Family 913-924; RC Kessler, EE Walters and MS Forthoyer, 'The Social Consequences of Psychiatric Disorders III: probability and marital stability' (1998) $155 \mathrm{Am}$ Journal Psychiatry 1092-1096; PR Amato, 'The consequences of divorce for adults and children' (2000) 62 Journal Marriage and Family 1269-1287; L Walker, The Battered Woman, (1979); British Medical Association, Domestic Violence: a healthcare issue?(1998); SD Platt, CJ Martin and SM Hunt, 'Housing, mould growth and symptomatic health state' (1989) British Medical Journal, 1643 - 1648; S Hunt, 'Housing related disorders' in J Charlton and S Murphy (eds) The Health of Adult Britain 1841-1994 (1997); S Nettleton and R Burrows, 'Which test, insecure homeownership and health: an exploratory analysis' (1998) 20 Social Health 731-735; SH Wilson and GM Walker, 'Unemployment and health: a review' (1993) 107 Public Health 153-162; and R Mayou, B Bryant and R Duttie, 'Psychiatric consequences of road traffic accidents', (1993) 307 British Medical Journal 647-651.

Public Space: The Journal of Law and Social Justice (2009) Vol 3, Art 7, pp 1-29. 


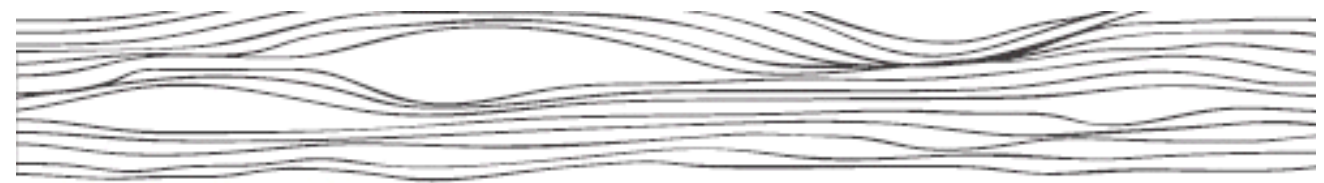

Public Space: The Journal of Law and Social Justice

CSJS findings also suggest that lone-parent families are particularly vulnerable to experience multiple problems. ${ }^{21}$ Moorhead et al also conducted research in 2004 into the advice needs of lone parents. ${ }^{22}$ Their research found that lone-parent families are a vulnerable and marginalised group; they have high needs, often have long-standing problems both legal and non-legal, they use a high number and diverse range of advice sources for help, the quality of service they receive is variable, and a large number of lone-parents do not seek help or struggle to find help they need. ${ }^{23}$

These selected results demonstrate how legal, health, social welfare and other problems are integrally connected. This implies the importance of training health and other professionals in problem identification, and appropriate referral and linkages upon the problem being identified. It also implies that for joined-up services to work, solutions and policies must be informed by the causes and manifestations of social exclusion. ${ }^{24}$

\section{Selected evidence from Australia}

Arguably, there has been less access to justice research in Australia than in England and Wales, possibly due to a lack of research funding and/or governmental interest. ${ }^{25}$

${ }^{21}$ A Buck, P Pleasence, NJ Balmer, A O'Grady and H Genn, 'Lone Parents and Civil Law: Their Experience of Problems and Their Advice Seeking Behaviour' (2004) 38 Social Policy and Administration.

${ }^{22}$ R Moorhead, M Sefton and G Douglas, The Advice Needs of Lone-parents (2004) One Parent Families.

23 Ibid, pg 9.

${ }^{24}$ A Buck, NJ Balmer and P Pleasence, 'Social Exclusion and Civil Law: Experience of Civil Justice problems among Vulnerable Groups' (2005) 39 Journal of Social Policy and Administration.302320.

25 Senate Legal and Constitutional References Committee, Inquiry into the Australian Legal Aid System: Second Report, (1997) and see also L Curran and M Noone, above n 4,pg 63 and M Noone, 'Access to Justice Research in Australia' (2006) 31 Alternative Law Journal. 30; but see the research by Hunter, Banks and Giddings on Australian innovations in legal aid services (C Banks, R Hunter and J Giddings Australian Innovations in Legal Aid Services: Balancing Cost and Client Needs (2006); and R Hunter, C Banks and J Giddings 'Australian Innovations in Legal Aid Services: Lessons from An Evaluation Study', in A Buck, P Pleasence and NJ Balmer (eds) Reaching Further: Innovation, Access and Quality in Legal Services (2009).

Public Space: The Journal of Law and Social Justice (2009) Vol 3, Art 7, pp 1-29. 


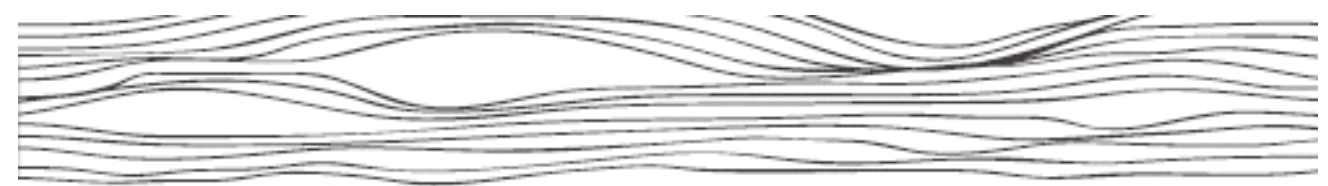

Public Space: The Journal of Law and Social Justice

However, recent developments, notably the commissioning of a nationwide legal needs survey by National Legal $\mathrm{Aid}^{26}$ (which comprises all of the statutory legal aid commissions around Australia) will provide new insight into the legal needs of Australians as well as filling a paucity of nationwide data. ${ }^{27}$ The research is being conducted by the New South Wales Law and Justice Foundation. The Foundation has previously conducted a series of (non-national) surveys ${ }^{\mathbf{2 8}}$ most notably its 'Justice Made to Measure: New South Wales Legal Needs Survey in Disadvantaged Areas' (JMTM). ${ }^{29}$ The findings reinforce CSJS findings.

In the JMTM, six disadvantaged areas were surveyed by telephone. These included three suburban, one provincial area and two rural areas. The survey was conducted on 2,431 residents over fifteen years of age with a response rate of between $24 \%$ and $34 \%$, and was a random sample.

In the disadvantaged areas surveyed, people had a high incidence of legal events over a one-year period. Two-thirds reported one or more legal events in the previous twelve months, which ranged from crime (27\%), housing $(23 \%)$, consumer $(22 \%)$ government (20\%) and accident/injury (19\%). The problems were of a nature that they tended to re-occur or co-occur. Some individuals with disabilities or chronic illness experienced a particularly wide range of legal events.

26 For more information see National Legal Aid <http://www.nla.aust.net.au/>.

${ }^{27}$ In 2004, the Australian Senate Legal and Constitutional Affairs Committee in its Final Report on Legal Aid Services lamented the lack of empirical data in Australia in relation to legal need. See $<$ http://www.aph.gov.au/Senate/committee/legcon_ctte/completed_inquiries/2002-

04/legalaidjustice/report/b01.htm.

${ }^{28}$ Other reports of the New South Wales Law and Justice Foundation in NSW include 'On the Edge of Justice: the legal needs of people with a mental illness in New South Wales' (2006); 'No Home, No Justice? The legal needs of homeless people in New South Wales' (2005) and 'The Legal Needs of Older People in New South Wales' (2004); Access to Justice and Legal Needs, Stage 1, Public Consultations (2003) and Qualitative Legal Needs Survey: Bega Valley (Pilot) (2003) available at https://www.lawfoundation.net.au/publications.

${ }^{29}$ C Cournarelous, Z Wei and A Zhou, Justice Made to Measure: New South Wales Legal Needs Survey in Disadvantaged Areas (2006) available at http://www.lawfoundation.net au/report/survey2006.

Public Space: The Journal of Law and Social Justice (2009) Vol 3, Art 7, pp 1-29. 


\section{Public Space: The Journal of Law and Social Justice}

There were substantial rates of inaction amongst those surveyed. Consistent with CSJS findings, a substantial proportion of people experienced barriers in seeking help in the first place. When they did seek help two-thirds found it from non-legal advisers. Sources of this advice included family and friends, local councils, trade unions, government, insurance companies, accountants, health and social services and schools.

The JMTM surveys revealed that people experienced delays in telephone advice (17\%), difficulty with appointments (11\%), and a lack of accessible service (8\%). The conclusions from these findings are:

- $\quad$ services needed to be more accessible;

- $\quad$ more community legal education was needed and it should be tailored where appropriate;

- $\quad$ non-legal professionals should be seen as gateways;

- $\quad$ a need for more co-ordination between legal services and non-legal services; and

- $\quad$ more client focussed responses, multi-dimensional responses, with greater co-ordination and co-operation between services. ${ }^{30}$

Other research conducted in Australia by Curran and Noone has taken a new approach to measuring access to justice. Their work commenced in 2003, after considerable struggles with the use of the term 'legal need' and its limitations. ${ }^{31}$ Their approach uses internationally recognised human rights standards as benchmarks against which to measure whether or not access to justice was realised. Indicators were developed to ascertain what would need to occur to reach the benchmarks. These were then tested against people's actual experience of their human rights.

\footnotetext{
${ }^{30}$ Ibid.

${ }^{31}$ L Curran and M Noone (2007), above n 4, pg 63.
}

Public Space: The Journal of Law and Social Justice (2009) Vol 3, Art 7, pp 1-29. 


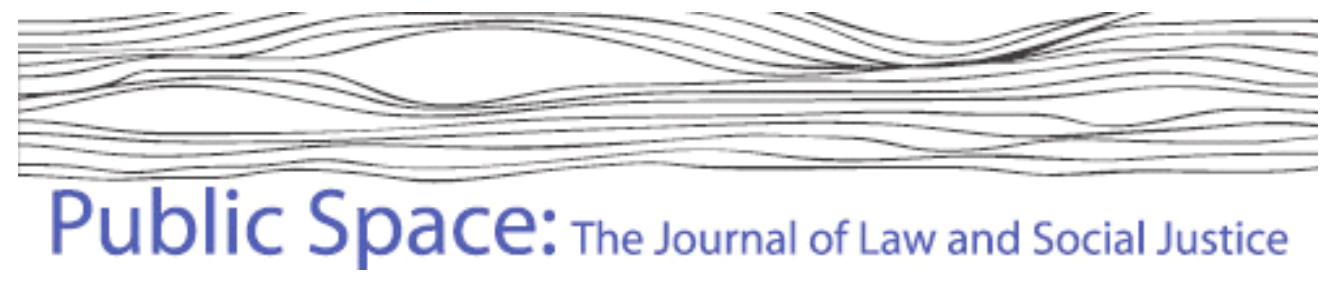

The project was a modest trial in West Heidelberg, Victoria, to pilot the methodology. ${ }^{32}$ A significant number of people living in the West Heidelberg area are reliant on social security. ${ }^{33}$ In addition, data at the time of the project from the West Heidelberg Community Legal Service indicated that issues around social security affected a high number of clients of the legal service. ${ }^{34}$ The research revealed that health, housing and social service providers as well as service users had very little knowledge or understanding of social security as a human right, or their rights at law. Few people were aware that there were legal aspects to their problems and that legal advice could be sought. Many were also unaware of their rights or of remedies when their right to social security was infringed, or when social security officers treated them inappropriately. Research participants expressed a high level of fear about reprisals for complaining about their treatment. Many believed if they challenged a decision or their treatment, they might jeopardise their remaining payments.

Without knowledge about the right to social security and norms of what appropriate treatment was, and in the absence of a capacity or confidence to pursue their right, Curran and Noone posit that it was unlikely that the right was going to be realised. In order to have a right to an effective remedy, knowledge of that right with the capacity and confidence to be prepared to exercise that right when it is threatened or curtailed, are necessary pre-conditions. Recent research findings in the United States by Sandefur come to similar conclusions. ${ }^{35}$ Sandefur ran focus groups with low and moderate-income residents in a mid-western American city, exploring problems involving money and housing. She found five rationales for inaction amongst the respondents, which included: shame, a sense of insufficient power, fear, gratitude due to previous experiences and frustrated resignation.

\footnotetext{
${ }^{32}$ Thanks to Kate Digney for her research assistance in this project.

${ }^{33}$ See data on the City of Banyule, http://www.id.com.au/banyule/commprofile/Default.asp?bhcp=1.

${ }^{34}$ CLSIS data for the last yearly quarter of 2005, which is maintained by the legal service, revealed that a high percentage of clients of the legal service were on social security.

35 See RL Sandefur, 'The Importance of Doing Nothing: Everyday Problems and Responses of Inaction', in P Pleasence, A Buck and NJ Balmer (eds), 'Transforming Lives: Law and Social Process', (2007).
}

Public Space: The Journal of Law and Social Justice (2009) Vol 3, Art 7, pp 1-29. 


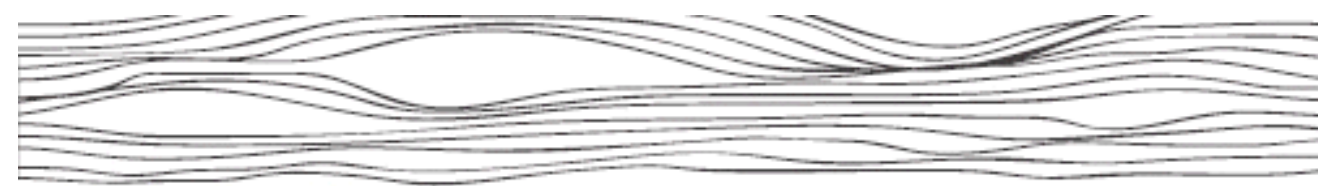

Public Space: The Journal of Law and Social Justice

\section{How research can inform policy developments}

In the UK, there has been a conscious effort to reduce social exclusion, a (contested) concept encompassing a combination of linked problems and caused not just by poverty, but also through discrimination, chronic ill-health and geographical or cultural isolation. ${ }^{36}$ The UK Labour Government established a Social Exclusion Unit (SEU) in 1997. ${ }^{37}$ The SEU defined social exclusion as, "a shorthand term for what can happen when people or areas suffer from a combination of linked problems such as unemployment, poor skills, low incomes, poor housing, high crime, bad health and family breakdown". ${ }^{38}$ Across the UK Government, social exclusion became a key policy tool, with substantial research conducted in the area. It has also been used to link the relevance of the provision of legal aid services with other departments and policy areas, such as social services and public health. There is considerable debate as to how effective the overall social exclusion policy has been, with a significant economic and social divide still in existence in the UK; and with research showing that inequality is still growing in some policy areas. ${ }^{39}$ This policy agenda in the UK has not, unsurprisingly, been free of controversy. In addition, the worldwide financial crisis brings new challenges.

In Australia, following the election of the Labor Government in 2007, a Minister for Social Inclusion and a Social Inclusion Unit and Board were established - around a decade after the Social Exclusion Unit was brought into being in the UK. A 'National

\footnotetext{
${ }^{36}$ See, for example, T Burkhardt, J Le Grand and D Piachaud, 'Introduction' in J Hills, J Le Grand and J Piachaud (eds) Understanding Social Exclusion (2002); Social Exclusion Unit Preventing Social Exclusion (2001).

${ }^{37} \mathrm{http}: / / w w w . s o c i a l i n c l u s i o n . g o v . a u /$ Initiatives/Pages/default/aspx.

${ }^{38}$ Social Exclusion Unit, Preventing Social Exclusion (2001).

39 See eg http://www.jrf.org.uk/knowledge/findings/socialpolicy/2164.asp; J Hills, T Sefton and K Stewart Towards a More Equal Society? Poverty, Inequality and Policy since 1997 (2009).
}

Public Space: The Journal of Law and Social Justice (2009) Vol 3, Art 7, pp 1-29. 


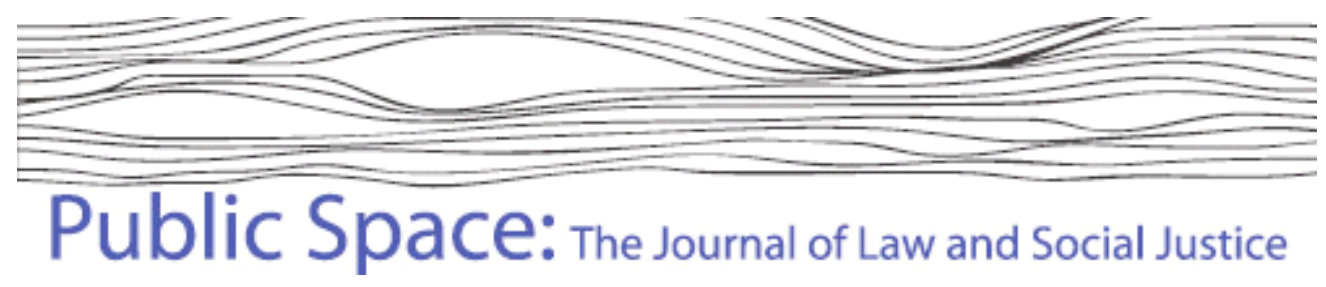

Compact' is being developed to strengthen relationships between government and the not-for-profit sector. Guiding principles for social inclusion have been developed. ${ }^{40}$

In regard to legal services, it has been argued that since the mid-1990s decisions around funding and placement of legal aid services have been based on political and funding exigencies in Australia, rather than on empirical information about adviceseeking behaviour and community need. ${ }^{41}$ In England and Wales, research findings highlighting the interconnectedness of problems, and the impact of civil justice problems on people's lives and health, are widely accepted by justice policy makers. So-called 'evidence-based policy' has also had much prominence ${ }^{42}$. At the same time, pressures on funding and value-for-money considerations have increased significantly over the last decade.

Two brief examples from England and Wales serve to highlight the impact of research: the LSC set out a community legal advice strategy in 2006, which aims to implement 'an integrated and seamless service'. Community legal advice centres (CLACs) and community legal advice networks (CLANs) are being developed across the country for delivery of combined services. The centres are jointly funded with local authorities and are to be seen as a single entity to provide an integrated and seamless social welfare law (SWL) service, including family law (the core SWL categories include community care, debt, employment, housing and welfare benefits problems). ${ }^{43}$ The (controversial) policy takes on board findings from the CSJS; in particular the importance of providing a range of legal advice services in one place, which people know about and which minimises multiple referrals. Moorhead et al's research on clustering also supports a policy of joined-up legal services. However,

40 'Gillard to Wage War on Poverty', The Age, 12 January 2008, 1.

${ }^{41}$ For a comprehensive discussion of the decision-making and funding climate in legal aid services in Australia see M Noone and S Tomsen, Lawyers in Conflict: Australian Lawyers and Legal Aid (2006).

${ }^{42}$ See A Buck, 'The Policy Demand for Social Research in Civil Justice: The UK Perspective' (2007) Zeitschrift für Rechtssoziologie.

${ }^{43}$ Legal Services Commission, Making Legal Rights a Reality: The Legal Services Commission Strategy for the Community Legal Service, 2006-2011 (2006).

Public Space: The Journal of Law and Social Justice (2009) Vol 3, Art 7, pp 1-29. 


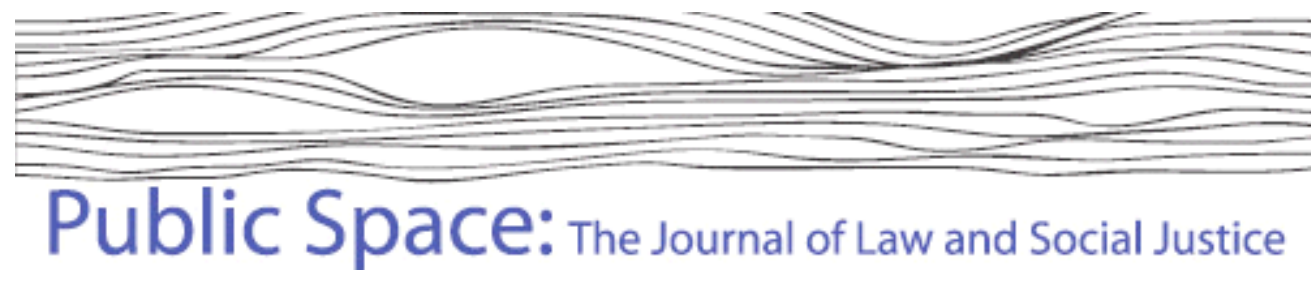

they raise the concern that the competitive model utilised for the new CLACs and CLANs may jeopardize LSC funding for other providers. ${ }^{44}$ Moorhead et al observe that the LSC has to recognize that there needs to be latitude for developing best practice. The LSRC now has responsibility for evaluating CLACs and CLANs over coming years, to help determine what does and does not work.

A further LSRC research project informing a policy development was the evaluation of the LSC's money advice outreach pilots. The pilots, operating from 2005-2008, were aimed at areas and groups facing high levels of deprivation and financial exclusion. The objective was to take legal and advice services to locations already frequented by people in potential need of debt advice, but where debt advice services cannot ordinarily be accessed (e.g. prisons, family and children centres, community centres). The multi-phased research and evaluation project ${ }^{45}$ demonstrated the importance of providing outreach advice to meet the specific needs of disadvantaged and 'hard-to-reach' individuals. Whilst the pilots are not continuing, building on the LSRC's early evaluation results showing high levels of financial exclusion and debt advice needs among prisoners, HM Treasury announced in December 2007 that the pilots would be reconfigured to focus on prisons, with $£ 5$ million funding. ${ }^{46}$

\section{Examples of delivery models from around the world}

The following examples of service delivery drawn from England, Australia and South Africa highlight the possibilities for co-located, outreach and holistic and integrated

${ }^{44} \mathrm{R}$ Moorhead, M Robinson, and Matrix Research and Consultancy, A Trouble Shared -Legal Problems Clusters in Solicitors and Advice Agencies (2006).

${ }^{45}$ A Buck 'Reaching Further Through Outreach Advice', in A Buck, P Pleasence and NJ Balmer (eds) Reaching Further: Innovation, Access and Quality in Legal Services (2009); A Buck, T Tam and C Fisher Putting Money Advice Where the Need is: Evaluating the Potential for Advice Provision in Different Outreach Locations (2007); L Day, S Collard and V Davies Money Advice Outreach Evaluation: The Provider and Partner Perspectives (2008); L Day, S Collard and C Hay Money Advice Outreach Evaluation: Qualitative Outcomes for Clients (2008) all available via www.lsrc.org.uk/publications.

${ }^{46}$ HM Treasury, Financial Inclusion: An Action Plan for 2008-11, (2007)

Public Space: The Journal of Law and Social Justice (2009) Vol 3, Art 7, pp 1-29. 


\section{Public Space: The Journal of Law and Social Justice}

service delivery. All models look at services in and for particularly disadvantaged communities. The models presented are only a small selection; many other innovative delivery models exist. The examples aim to highlight the potential of alternative models. It is not within the remit of this article to systematically appraise and evaluate the success of the below examples.

Homelessness Clinic, Public Interest Law Clearing House (PILCH), Victoria, Australia

The Homeless Persons' Legal Clinic was established in October 2001. It emerged from a study by the Managing Solicitor of the Public Interest Law Clearing House, who examined models of service delivery to the disadvantaged in the United States, as part of a Churchill Fellowship. ${ }^{47}$ Her ideas eventually saw consultation with a broad range of accommodation, welfare and legal services into how a model might work, and how the agencies might intersect and support a legal service to the homeless. Since its initiation, the project has been auspiced by the Public Interest Law Clearing House and receives funding from a range of sources (government and nongovernment). Initially, there was some difficulty in securing ongoing funding. With its success, it has become easier - whilst remaining a continuous challenge. The project now provides free legal assistance to, and advocacy on behalf of, people who are homeless or at risk of being homeless. Services are provided by pro bono lawyers from participating law firms and legal departments. Each firm is responsible for the provision of services at one or two host agencies on a weekly basis. The clinic also engages in analysing systemic issues around how policies and legislation impact upon the homeless, in order to promote human rights and identify any gaps in services. ${ }^{48}$

What makes this model innovative is that the lawyers at the clinic provide civil and administrative legal services at crisis accommodation centres and welfare agencies

\footnotetext{
${ }^{47}$ Undertaken by Caitlin English, Managing Solicitor of the Public Interest Law Clearing House in 1999.

${ }^{48}$ P Lynch, 'Human Rights Lawyering for People Experiencing Homelessness' (2004) 4 Australian Journal of Human Rights.
}

Public Space: The Journal of Law and Social Justice (2009) Vol 3, Art 7, pp 1-29. 


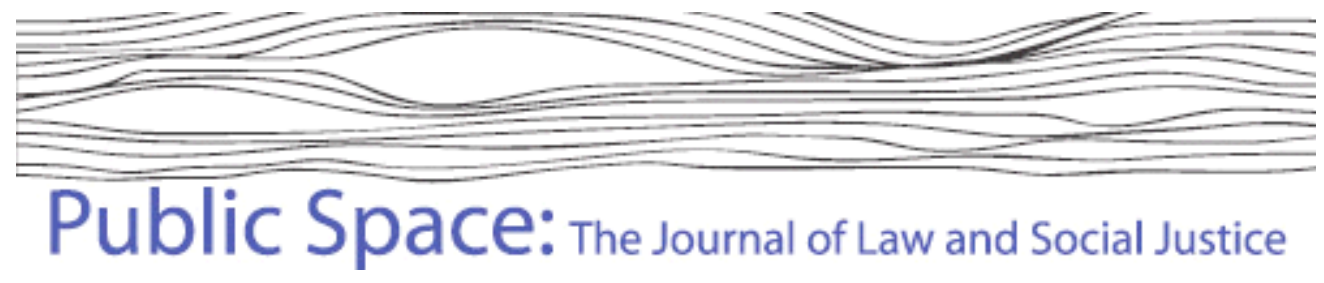

where the clients are most likely to go to seek other services, food or emergency accommodation. In line with the aims of the LSC's money advice outreach pilots, the legal advice is offered at locations where the clients, in this case the homeless, are likely to be; rather than expecting the homeless to find the legal service and make appointments. Some of the agencies which participate include: Melbourne Citymission, 'The Big Issue', St Vincent de Paul Society, the Salvation Army, Anglicare, Urban Seed, Hanover, Vacro ${ }^{49}$ and Homeground Housing. The Clinic also consults with a Consumer Advisory Group made up of people who have experienced homelessness or who are currently homeless. ${ }^{50}$ This ensures ongoing connectedness of the clinic, empowerment of homeless people and maintains the relevance of the service to people who are homeless. ${ }^{51}$ The project sees its lawyers as "crossing the gap', as it requires that lawyers acquire exposure to and understanding of clients' social, cultural and economic perspectives and lives. ${ }^{52}$ Lynch argues the need for the legal profession to engage with social service providers when working with disadvantaged members of the community. ${ }^{53}$

A further strength of the model is that it takes a non-hierarchical and client focussed approach to lawyering. It has been argued that this approach, along with the Community Advisory Group which guides the clinic (made up of homeless people), guards against the "paternalistic substitution of perceived 'best interests' for what the client says he or she wants (which) ${ }^{54}$ is the antithesis of empathy and is profoundly disempowering." ${ }^{55}$

\footnotetext{
${ }^{49}$ The Victorian Association for the Care and Resettlement of Offenders.

${ }^{50} \mathrm{See}$

http://www.pilch.org.au/html/s02_article/article_view.asp?id=133\&nav_cat_id=172\&nav_top_id=60 $\& \mathrm{dsb}=531$

${ }^{51}$ The Consumer Advisory Group not only fulfils a role in advising the Homelessness Clinic but now, after training of its members, sees people who are or were once homeless, training the community about issues that can confront homeless people, training lawyers around their interviewing skills and informing homeless people about how to access services.

${ }^{52}$ See above n 48.

${ }^{53}$ Ibid.

${ }^{54}$ Brackets inserted by authors to clarify.

${ }^{55}$ See above $\mathrm{n} 48$.
}

Public Space: The Journal of Law and Social Justice (2009) Vol 3, Art 7, pp 1-29. 


\section{Public Space: The Journal of Law and Social Justice}

The West Heidelberg Community Legal Service/Banyule Community Health Service/ La Trobe University Partnership, Victoria, Australia

The West Heidelberg Community Legal Service commenced operation in $1975 .{ }^{56}$ This is a three-way partnership between the legal service, the Banyule Community Health Service and La Trobe University. In the initial stages from October 1976 1978, the legal service operated with the voluntary service of a local practitioner, John Cain (later to become Premier of Victoria) who worked from an office in the West Heidelberg Community Health Service. The health centre was established in 1975 after a poverty inquiry identified West Heidelberg as an area of high need for services. In early 1978, following discussions between the community centre and La Trobe University, a lecturer position in legal aid was funded and through this position legal services were provided to the West Heidelberg community. The lecturer, Phil Molan, along with local community members, then applied for funding from government which was secured in 1981 and started with a modest $\$ 7,500$. The service now employs three full time staff providing services alongside the La Trobe Law lecturer/solicitor who still delivers legal services to the community through the student law clinic. The legal service operates along a model of problem-solving, appropriate referral, representation and advice. It also takes an active involvement in law reform and community education, emerging out of identified client problems and systemic issues.

Coverage by the legal service has to be limited due to modest funding and high levels of need. Research into social disadvantage in Victoria conducted in 2006, found West Heidelberg ranked 20 out of 726 postcodes for general disadvantage. This level of disadvantage was similar in 1999 and 2004. The major indicators the research looked at were: computer use, internet access, low income families, post-school qualifications, disability/sickness support, interventions by State child protection

\footnotetext{
${ }^{56}$ This was a response to high levels of legal need identified in the area. See M Cass and R Sackville, Legal Needs of the Poor (1975).
}

Public Space: The Journal of Law and Social Justice (2009) Vol 3, Art 7, pp 1-29. 


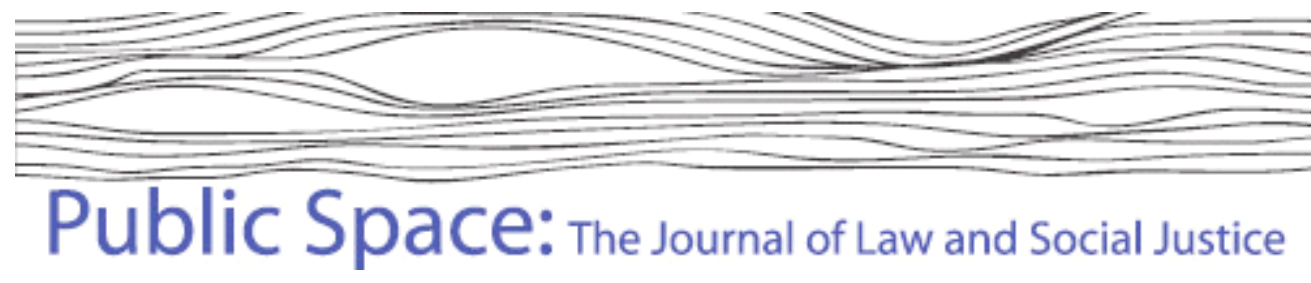

agencies, early school leavers, low work skills, final year schooling incomplete, drug and alcohol dependency and criminal convictions. ${ }^{57}$

Integral to the legal service's approach is its ongoing relationship and co-location with the health service. To use the language of the health sphere, the legal service along with the health centre has endeavoured to implement an 'integrated care approach'. It adheres to privacy laws and lawyer client privilege through a separate filing system and a strict client consent regime within the legal service. The health service also provides allied health and social welfare services. It employs doctors, nurses, nutritionists, dentists, psychiatrists and psychologists, but also professionals from a broader range of disciplines: drug and alcohol counsellors, problem gambling support services, financial counsellors and neighbourhood renewal personnel. The health service "promotes a multi-disciplinary approach to community health through team work and cooperation with other health and welfare providers." It "encourages those in necessitous circumstances to have access to the range of health and welfare services provided, providing health and welfare services promoting a preventative and educative approach." ${ }^{58}$ There is research currently being conducted by Associate Professor Mary Anne Noone of La Trobe University examining the impact on clients of the West Heidelberg Community Legal Service/Banyule Community Health integrated service model. This research is also examining how referrals, processes and relationships between the two agencies work.

Interlinked services on one site, such as those of the West Heidelberg Community Legal Service and the array of professionals in health and social service disciplines at the health service, has provided access to people who might not otherwise have received help. What enables the service to access people who otherwise would not seek out help - and to resolve legal and a range of problems in concert - is the heavy reliance it places on relationships built on trust. Contact between the onsite workers of

\footnotetext{
${ }^{57} \mathrm{~T}$ Vinson, 'Dropping off the edge: the distribution of disadvantage in Australia' (2007) Jesuit Social Services Australia 66-70.

${ }^{58}$ Banyule Community Health Service Inc Brochure, Your Health Service (2003).
}

Public Space: The Journal of Law and Social Justice (2009) Vol 3, Art 7, pp 1-29. 


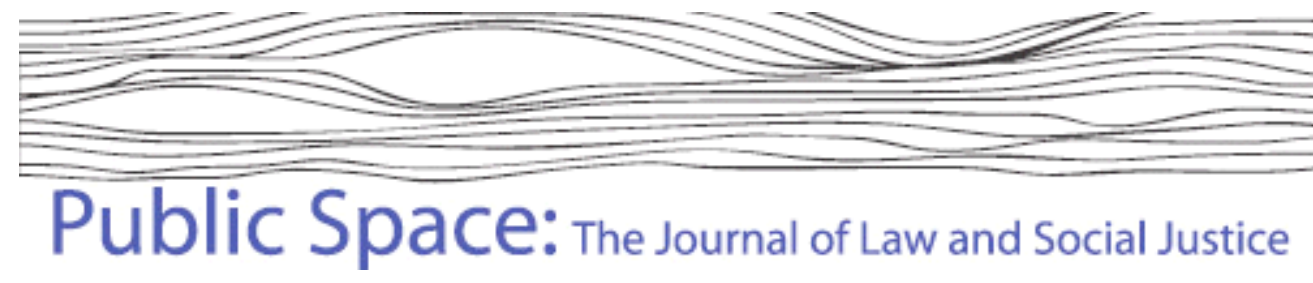

the health and welfare services is also crucial. Legal issues are seen as part of a complicated web of other associated problems that might include mental health, health generally, financial issues and so on. ${ }^{59}$ The health service works on a case management basis; the aim is to solve all the client/patient's problems rather than dealing with each one in isolation. Working on an array of issues with the client, can result in the client not feeling alone or overwhelmed. ${ }^{60}$ The legal service, like the homelessness clinic described previously, also has regular community advisory opportunities to ensure it reflects community need. There is a community based Committee of Management and regular forums with local people on issues that affect them. This is consistent with both an empowerment model but also a regular conferral model. ${ }^{61}$

By working within a broader context of the realities of clients' lives and making appropriate referrals and obtaining back referrals, the legal service works closely with experts in other fields. The cross referrals aim to avoid the client having to navigate the complex labyrinth of social, health and support services they may have no hope of or stamina for engaging with.

The ongoing challenge for the legal service is that it is still largely run by appointment and has had to close its outreach advice service. This is due to limited funding and growth in needs in other local geographical areas. Another challenge is that different services are funded using different outcome models. Whilst recognizing the importance of demonstrating outcomes to funders, these set 'outcomes' can come into conflict with the holistic approach.

\footnotetext{
${ }^{59}$ M Noone, 'They all come in one door' - The transformative potential of an integrated service model: A study of the West Heidelberg Community Legal Service', in P Pleasence, A Buck and NJ Balmer (eds), Transforming Lives: Law and Social Process (2007) and see L Curran, 'Making Connections: The Benefits of Working Holistically to Resolve People's Legal problems' (2004) 12 E-law Murdoch University Electronic Journal of Law available at $\mathrm{http} / /$ www.murdoch.edu.au/elaw/issues/v12n1_2/Curran12_1.html.

${ }^{60}$ Comment by a client to the student lawyer, May 2007.

${ }^{61}$ An illustration of this is the formation by the health service of a Public Tenants Users Association. The Chair of the legal service is actively involved in this community action group.
}

Public Space: The Journal of Law and Social Justice (2009) Vol 3, Art 7, pp 1-29. 


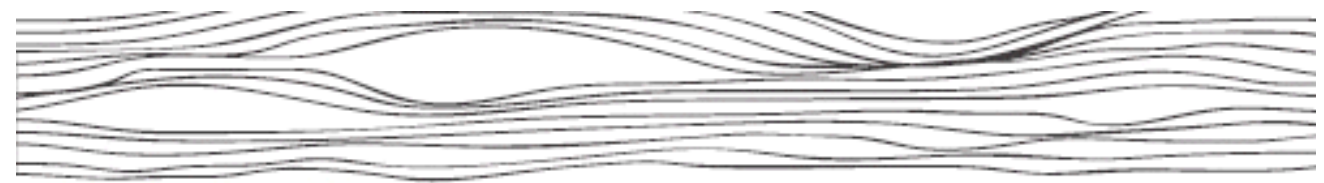

Public Space: The Journal of Law and Social Justice

\section{St Petroc's Society for Single Homeless People in Cornwall, England}

The St Petroc's Society provides accommodation and social care services to meet the needs of single homeless people. ${ }^{62}$ The service was formed in 1986 and sees a colocation of advice services - but these do not include legal service advisers. St Petroc's Society has support from churches, local communities and dedicated groups of 'friends' or 'partners'. ${ }^{63}$

Single homeless people often fall outside the responsibility of statutory authorities. Very often they are sleeping 'rough' and may have a range of difficulties, including drug or alcohol dependency, mental ill health, relationship problems or an offending lifestyle, which contribute to their homelessness and social exclusion. ${ }^{64}$ St Petroc's Society aims to give 'realistic assistance,' rather than clients being met with 'a mesh of unrealistic requirements'. ${ }^{65}$ They link up with a range of agencies on site. One is the Health for Homelessness Team, which offers a primary health care service with a doctor, a nurse, a drug dependency psychiatric nurse and a specialist alcohol and homelessness social worker. Another agency is 'Breadline', which has a café, office and a medical room and also responds to accommodation enquiries, finds housing and provides advice on benefits. Other agencies also visit the centre, including a Citizens Advice Bureau and the YMCA.

As well as resettling homeless people, the centre has a youth worker and a youth accommodation worker funded through Comic Relief, as a joint venture between St Petroc's and the Youth Offending Team. This service seeks to offers young people ongoing advice and support in a safe and settled environment so they are able to build

\footnotetext{
${ }^{62}$ Thanks to Ash Patel of the LSRC for directing the authors to this project and for enabling them to view his interviews with the agency.

${ }^{63}$ St Petroc's Society, Annual Report 2005-2006, Cornwall.

${ }^{64} \mathrm{http}: / /$ www.housingnet.co.uk/housingnet-html/Saint_Petroc_s_Society.html; Social Exclusion Unit, Rough Sleeping (1998).

${ }^{65}$ See above $\mathrm{n} 63$.
}

Public Space: The Journal of Law and Social Justice (2009) Vol 3, Art 7, pp 1-29. 


\section{Public Space: The Journal of Law and Social Justice}

skills, confidence and self-esteem. It links with the Youth Accommodation Support Scheme, which obtains and secures accommodation in the private sector and encourages the pursuit of training and education. The perceived success of the program is referred to by the fact that clients can access one service via the other with a sense of well-being, and in a form which promotes self esteem. ${ }^{66}$ It is noted that many homeless people seen by the service do not see their health as a priority although their health is susceptible to being poor because they sleep rough. The patients/clients would be unlikely to turn up at a general practitioner's service themselves. However, as they are in need of housing support they will access the accommodation service, linked into the health service on site. Many present with issues such as malnutrition, exposure, early life trauma and/or family breakdown, have been victims of physical and sexual abuse, learning disabilities, and use drugs and alcohol to self medicate. ${ }^{67}$ Clients have self-referred after they hear of the service through others who have trusted the service in the past. The centre tries to work closely with local police to enable them to call for assistance rather than taking a law and order approach which can sometimes exacerbate the problems of homeless people. $^{68}$

One gap in services provided on site is the availability of legal advice. However, St Petroc's has found that usually there is little need for specialist legal advice - though of course many of the problems the centre deals with have a general rights-based dimension. If significant legal problems appear, the centre's policy is to actively refer clients to established legal advice specialists.

\footnotetext{
${ }^{66}$ Ibid.

${ }^{67}$ Ibid.

${ }^{68}$ Unpublished interview with worker at St Petroc's and Ash Patel LSRC, 2007.
}

Public Space: The Journal of Law and Social Justice (2009) Vol 3, Art 7, pp 1-29. 


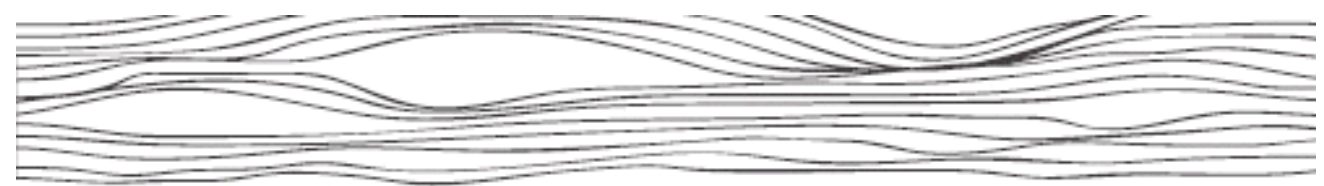

Public Space: The Journal of Law and Social Justice

\section{The Aids Law Project, Johannesburg, South Africa}

The Aids Law Project (ALP) takes on strategic test cases, lobbies and undertakes law reform activities. In its early days, the ALP would do considerable client casework but this has shifted so that it uses its limited resources to make the most impact. ${ }^{69}$

The focus of ALP's work is to enable people with HIV/Aids to have access to adequate health care and treatment in both the private and public sectors; and to enable those who experience discrimination and unfair treatment gain access to legal remedies and to protect their fundamental rights. ${ }^{70}$

The project carries out litigation and legal advocacy campaigns to counter wrongs that have occurred, to establish legal precedents, to prevent human rights abuses from occurring again and to build capacity within existing legal advice service providers to provide free legal advice. The ALP carries out research, supports policy formulation, suggests legislative change, and conducts legal campaigns to remove barriers that unfairly limit access to health care services. It also raises awareness in government of human rights issues, monitors, lobbies and engages in advocacy. ${ }^{71}$ Examples of test cases strategically undertaken have been around vulnerable people in the work place, with a particular focus on domestic workers, private security industry workers, miners and health care workers. Workers in these sectors face discrimination or poor working conditions that can impact on their health conditions.

In South Africa, significant issues of poverty and cultural segregation remain, even though apartheid is officially at an end. Organisations with minimal resources have

\footnotetext{
${ }^{69}$ Discussion between Liz Curran and the Acting Director, Aids Law Project, 16 July 2007.

${ }^{70}$ Aids Law Project, Annual Review (2005-2006), Centre for Applied Legal Studies, University of Witwatersrand.

${ }^{71}$ Ibid.
}

Public Space: The Journal of Law and Social Justice (2009) Vol 3, Art 7, pp 1-29. 


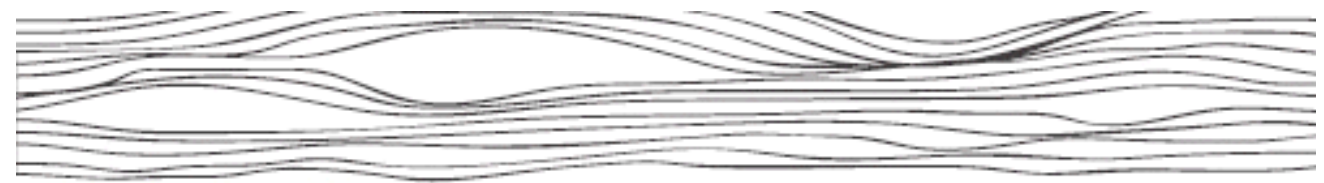

Public Space: The Journal of Law and Social Justice

had to be innovative, stretching their resources so that maximum impact can be made. ALP has had to focus on how to refer clients where there is no public interest issue. This means that ALP has engaged in training of non-government organisations on legal issues, and training legal services about issues affecting people with Aids. This has led to increasingly close relationships between the ALP and a range of agencies with which they work, which are often located in poor townships. These agencies can then identify trends or treatment and, where there is a significant public interest, refer the issue to the ALP. This has meant that legal issues and human rights abuses do not remain unattended to and are referred for action by ALP rather than ignored. ${ }^{72}$

A perceived challenge for the ALP is that many of the supporters from whom they received funding have taken the view that, now there is a Constitution in place in South Africa, 'all will be well'. Some philanthropic foundations have withdrawn funds whereas others focus on funding individual projects with very specific aims and accountabilities. This means that endeavours to overcome systemic injustice and build frameworks that are sustainable can become fragmented or piecemeal. The ALP tries, where possible, to broaden the benefit of individual projects but such endeavours can, arguably, come into conflict with the often tightly prescribed terms of the project work required by philanthropic foundations. This is not only a difficulty for the ALP but also for other organisations such as the Legal Service Resource Centre, which does significant test case work and has represented many South Africans during and since apartheid. ${ }^{73}$

\footnotetext{
${ }^{72}$ See above $\mathrm{n} 69$.

${ }^{73}$ Paragraph based on discussions between Liz Curran and the Legal Service Resource Centre, 3 July 2007.
}

Public Space: The Journal of Law and Social Justice (2009) Vol 3, Art 7, pp 1-29. 


\section{Public Space: The Journal of Law and Social Justice}

\section{Delivery of legal aid services to vulnerable and disadvantaged groups: key issues to consider}

\section{Coordination and resourcing of services}

There is a key role for government in ensuring an appropriate environment and funding resources, so services can develop the methods and provision that will enable people to benefit from early and effective advice. ${ }^{74}$ At the same time, it is recognized that legal aid jurisdictions are facing challenging times, with fixed budgets and competition for resources between different areas of public service delivery.

Clients coping with many years of social exclusion or a dramatic worsening of their health or lifestyle and poor levels of educational attainment and self esteem are often ill equipped to deal with complex bureaucracies or hostile opponents. ${ }^{75}$ In a recent UK Government report on social exclusion, the advantage of "providing tailored programmes of support built around strong and persistent relationships with those at risk' is stressed. ${ }^{76}$ This ties in with the earlier mentioned research ${ }^{77}$ on money outreach advice, which illustrated that feelings of trust are important to potential service users experiencing social and financial exclusion.

Joining up services is likely to result in people's problems being dealt with in the context of causes and consequences, rather than in isolation. A coordinated approach, which recognizes that health care and welfare professionals have a role to play in identifying those who are vulnerable to civil justice problems, can help to prevent the degeneration of circumstances that can lead to further problems. ${ }^{78}$ In order to overcome the range of barriers that exist for some vulnerable groups, 'dedicated

\footnotetext{
${ }^{74}$ P Pleasence, A Buck, NJ Balmer, A O'Grady, H Genn and M Smith, Causes of Action: Civil Law and Social Justice (2004).

${ }^{75}$ See Above n 43.

${ }^{76}$ Social Exclusion Taskforce, Reaching Out: An Action Plan for Social Exclusion (2006), pg 9.

${ }^{77}$ See above n 45 .

${ }^{78}$ See above $n 7$.
}

Public Space: The Journal of Law and Social Justice (2009) Vol 3, Art 7, pp 1-29. 


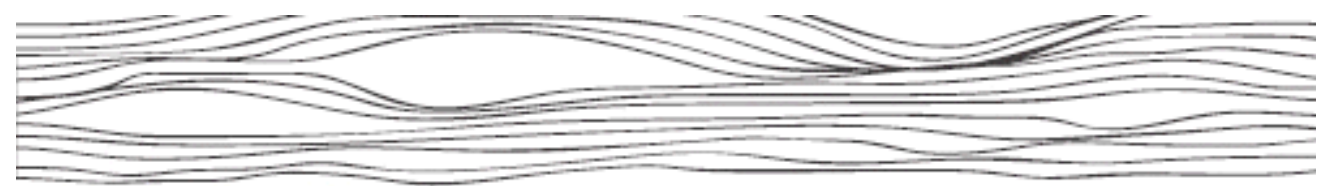

Public Space: The Journal of Law and Social Justice

advice services could mirror more the needs and behaviour of those who wish to use them' ${ }^{79}$ This requires alternative methods of delivery, as discussed below.

\section{Alternative methods of delivery}

The CSJS reveals that vulnerable and disadvantaged groups are most likely to experience civil justice problems. Sustained effort is needed to reach these people and move beyond the traditional models of advice service delivery. These traditional models involve people having to come to a legal advice point and make appointments; they can involve traditional narrow legal interviewing techniques, which sometimes rely too heavily on a hierarchical model.

Moorhead et al found that practitioners' understanding of holistic provision appeared confined to notions such as putting the client's problems in context and trying, with mixed success, to ensure clients can be sign-posted to appropriate providers when the initial adviser cannot deal with a particular problem. Broader notions of holistic practice, such as tackling social as well as legal problems, were not accorded much attention by practitioners. ${ }^{80}$ Legal services need to actively acknowledge barriers and address their service delivery to ensure it is connected, accessible and responsive. This includes awareness of cultural, economic, health and deprivation issues.

The experience of the Aids Law Project in South Africa reveals the importance of grass roots advocacy in specific contexts; especially for those who are excluded or who have little voice or power, and in communities with little infrastructure, access to services, a lack of hope and disenchantment. Empowerment and capacity building are likely to be critical for such communities. ${ }^{81}$

\footnotetext{
${ }^{79} \mathrm{R}$ Smith, Justice: Redressing the Balance (1997).

${ }^{80}$ See above $\mathrm{n} 44$

${ }^{81}$ However, see for a detailed discussion on empowerment in relation to self-help, highlighting the importance of 'no nonsense' practical assistance: M Lawler, J Giddings and M Robertson " "Maybe a Solicitor Needs to Know that Sort of Thing But I Don't” User Perspectives on the Utility of Legal
}

Public Space: The Journal of Law and Social Justice (2009) Vol 3, Art 7, pp 1-29. 


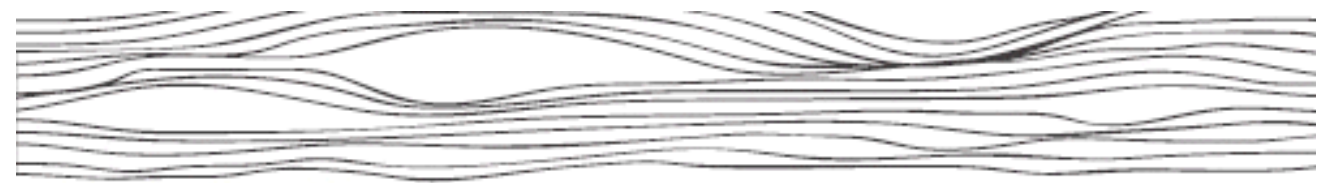

Public Space: The Journal of Law and Social Justice

The advantages of outreach advice are now also well documented. ${ }^{82}$ By delivering services at locations where people with problems are likely to be, outreach advice has the potential to reach out to 'hard-to-reach' and deprived groups. Accessibility is frequently a factor in whether or not people seek advice, with familiarity, trust and friendliness being equally important. Offering a range of delivery channels, such as face-to-face, Internet, telephone or videolink is also important.

Dealing with all problems together, rather than in isolation, and through cooperation between services, has the potential to improve clients' outcomes. This may mean publicly funded services require greater autonomy in identifying issues and responding to clients in their individual contexts to resolve their problems.

\section{The role of community legal education}

Over recent years, there has been increasing policy concern in the UK as to whether citizens are equipped with sufficient legal 'know-how'. In January 2006 the Department for Constitutional Affairs (DCA), now Ministry of Justice, announced a Public Legal Education and Support (PLEAS) Task Force. The move came after the Legal Action Group, the Citizenship Foundation and the Advice Services Alliance urged a national strategy to fund public legal education on citizens' rights and knowledge of the law. ${ }^{83}$ The Task Force published a report in July 2007, in which a number of strategic tasks were identified: creating a coherent focus and identity for public legal education; overcoming the fragmented nature of current provision;

Self-Help Resources (2009) in A Buck, P Pleasence and NJ Balmer (eds) Reaching Further: Innovation, Access and Quality in Legal Services (2009).

${ }^{82}$ For example, S Dewson, S Davis. and J Casebourne, 'Maximising the role of outreach in client engagement' (2006) DWP Research Report 326; A Buck 'Reaching Further Through Outreach Advice', in A Buck, P Pleasence and NJ Balmer (eds) Reaching Further: Innovation, Access and Quality in Legal Services (2009).

${ }^{83}$ Advice Services Alliance, Citizenship Foundation, Legal Action Group, Towards a National Strategy for Public Legal Education (2004); Advice Services Alliance, Citizenship Foundation, Legal Action Group, Public Legal Education: A Proposal for Development (2005).

Public Space: The Journal of Law and Social Justice (2009) Vol 3, Art 7, pp 1-29. 


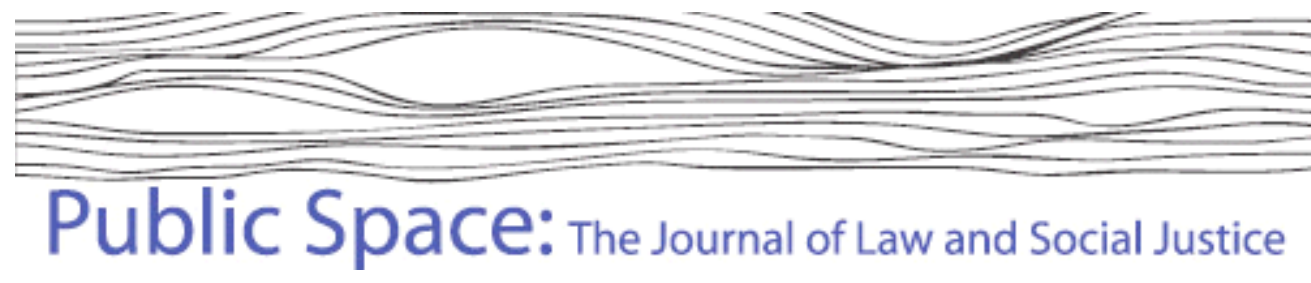

developing and spreading good practice; and, securing sustainable funding. ${ }^{84}$ Following the Task Force's report, Plenet (Public Legal Education Network) was established to continue building, among other aims, the body of knowledge of what makes for successful public legal education.

In Australia most legal aid commissions have a community legal education requirement in their service delivery models and/or have a statutory obligation to deliver legal education in addition to the case-work these legal aid commissions undertake. There are 207 community legal centres in Australia, which provide legal services to approximately 350,000 clients per year. ${ }^{85}$ Most legal centres also have a community legal education component in their service. Community legal education has therefore been an integrated part of the legal service framework from which legal aid commission and community legal centres have operated since the late 1970s.

The LSRC's annexe to the PLEAS Task Force report sets out findings from the CSJS that have education implications. ${ }^{86}$ Results clearly demonstrate the negative impact of knowledge gaps - increased rates of inaction, more failed attempts to obtain advice, more negative consequences as a result of problems, and a decreased likelihood of positive problem outcomes and meeting objectives. Crucially, the research report points to vulnerable groups being more likely to choose inappropriate advice-seeking strategies and have knowledge, skills and confidence gaps.

Successful public legal education initiatives have the potential to increase social justice. Community legal education, if located within communities and based on a community development model, may be effective in reducing current barriers in

\footnotetext{
${ }^{84}$ PLEAS Task Force, Developing Capable Citizens: The Role of Public Legal Education (2007).

${ }^{85}$ National Association of Community Legal Centres, Submission 84, 3 referred to in the Senate Legal and Constitutional References Committee available at http://www.aph.gov.au/senate/committee/legcon_ctte/completed_inquiries.

${ }^{86}$ A Buck, P Pleasence and NJ Balmer Education Implications from the English and Welsh Civil and Social Justice Survey (2007) available at www.pleas.org.uk; see also A Buck, P Pleasence and NJ Balmer 'Do Citizens Know How to Deal with Legal Issues? Some Empirical Insights'(2008) 4 Journal of Social Policy.
}

Public Space: The Journal of Law and Social Justice (2009) Vol 3, Art 7, pp 1-29. 


\section{Public Space: The Journal of Law and Social Justice}

accessing services and filling community knowledge gaps. Training by service providers of service users can demystify the legal system and attempt to provide the basic knowledge people need to enforce their rights, or to seek help in resolving their problems. Such education should recognise and heed people's educational attainments and cognitive abilities and be adapted using teaching pedagogy. Legal education is most helpful when there is a problem at hand and so it should target people at this stage of receptiveness. Timely education is crucial if a behavioural change is to be achieved.

Despite the huge potential of public legal education, the relative merits of resource allocation between advice services and public legal education requires a close examination. There is also the challenge of ensuring sustainability, a coordinated approach and best-practice learning.

\section{Conclusions}

In 1997, Smith outlined a number of principles to guide legal aid policy. These principles included: the interests of the citizen not the interests of providers should be predominate in policies regarding access to justice; access to justice requires policies which deploy every possible means towards attaining their goal, including reform of substantive law, precedent, education, information and legal services; policies on legal services need to deploy a portfolio approach involving a wide range of provision, some publicly funded and some not, some provided by lawyers and some not, with integration of approach being the key; programmes offered must take account of the realistic levels of resources but these should be seen as limiting policies rather than defining them; and, within civil law, more attention should be given to the particular legal needs of poor people. ${ }^{87}$ These principles form useful yardsticks for

\footnotetext{
${ }^{87}$ See above $n 79$.
}

Public Space: The Journal of Law and Social Justice (2009) Vol 3, Art 7, pp 1-29. 


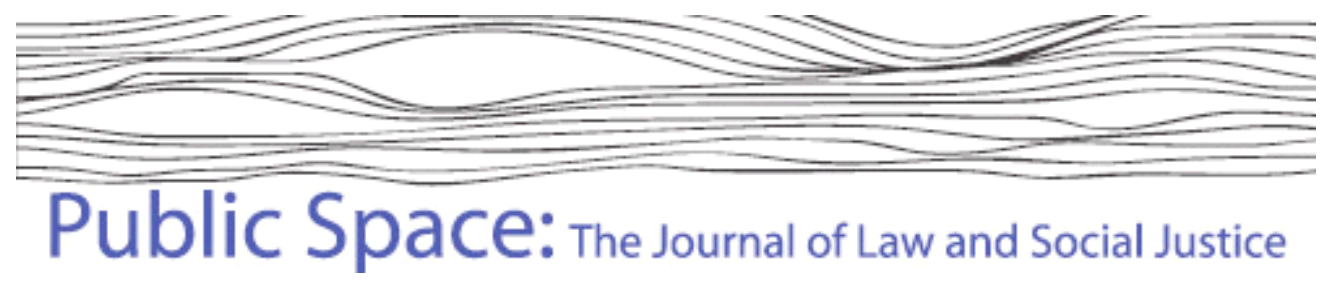

this article's focus on the delivery of legal advice to marginalised and vulnerable groups. ${ }^{88}$ Much of the research and delivery models discussed in this article have touched on these principles. As Smith's principles highlight, it is not always easy to divorce good service delivery from the pressures of resources, funding and politics. This is recognised as the challenging climate within which decision-makers, funders and those delivering services operate.

This article has drawn on research and selected service delivery models to illustrate how different communities in different contexts require different responses. The issues confronting indigenous Australians who often lack English language skills, live in remote communities and without access to basic services such as water and electricity may be different to the needs of newly arrived communities in England. Accordingly, there has to be room for flexibility and innovation to reflect the needs of local communities and individuals within those communities. Recognising that each client is different and problems stem from different life circumstances is key. Services ought to be able to deal with clients in a non-judgemental and non-patronising way, acknowledging that clients are multi-dimensional and active agents.

There are a range of disciplines that can help understand why people behave, and respond to problems, in certain ways. For example, drawing on behavioural economics and psychology to understand an individual's propensity to engage with their creditors, Summers et $\mathrm{al}^{89}$ highlight how people's behaviour is not always rational. Decision-making is influenced by many different factors. This highlights the complexity of human behaviour and confirms that a multi-dimensional approach to planning and delivering legal advice services is required. Self-esteem, ability to cope, entrenched avoidance behaviour, life circumstances, educational attainment and support networks are all factors that need to be taken into account, alongside anxiety

\footnotetext{
${ }^{88}$ Ibid.

${ }^{89}$ B Summers, D Read, and F Fylan, Literature in the Areas of Behavioural Economics and Psychology Relevant to the Understanding of an Individual's Propensity to Engage with their Creditors (2005) available at: www.dca.gov.uk/review_debt_research.pdf.
}

Public Space: The Journal of Law and Social Justice (2009) Vol 3, Art 7, pp 1-29. 


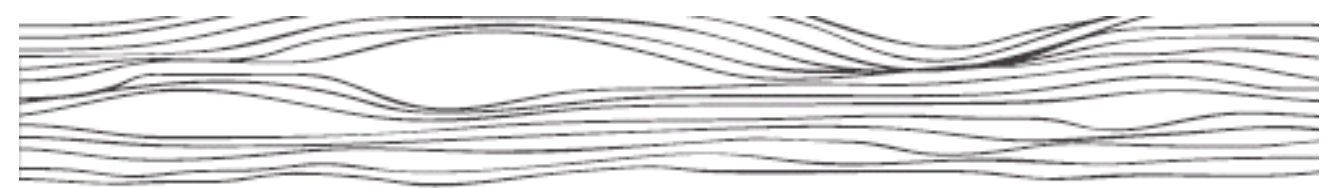

Public Space: The Journal of Law and Social Justice

about the implications of dealing with a problem; and the wider social and political context.

This article has highlighted research showing how people's legal problems are integrally connected to social issues and to health and well-being, and that there are ways of reaching people by reconfiguring how services are delivered. It is hoped the article will provide an impetus for further research, leading to strategies that understand the complex and compounding nature of legal issues, poverty and social exclusion, and make providers and funders aware of the need for innovative service delivery.

Public Space: The Journal of Law and Social Justice (2009) Vol 3, Art 7, pp 1-29. 